to foresee how timber resources will need to be conserved or increased in relation to the known world availability and world requirements. The picture is far from rosy, but with increased knowledge of the cultivation and use of fast-growing species immediate action can be expected to safeguard the situation. The aim of Mr. G. B. Ryle's presidential address to Section $\mathrm{K} *$ (Forestry) is to express some general thoughts as a challenge to our sense of urgency.

The British forest policy, hitherto based largely on the need to build up a reserve of growing timber as a safeguard in the event of another war, has now moved towards the need to maintain and increase forest production for economic and social reasons, to ensure the improvement of conditions in the poorer upland areas where grazing husbandry is failing to support a modern educated population and to improve the broad use of rural land also for the recreational benefit of the people as a whole.
The development of high-production forestry since 1919 is already creating an intense interest among industrialists, and as more supplies of the raw material become available so the building of new wood pulp factories, particle board mills and sawmills is following. As Mr. Ryle points out, the forest has much to offer to an industrial society in addition to its direct provision of an industrial product. By a close collaboration with the National Parks Commission and the Nature Conservancy so the forest is providing additional recreational facilities and opportunities for biological study equal to their national parks and their nature reserves.

The forest in a highly populated country must not be managed simply as a timber-producing factory. It is a storehouse of industrial wealth, of animal and plant communities and a place for recreation for the townsman. It is hoped that the townsman will collaborate to preserve this growing heritage.

\title{
RESPONSIBILITY AND EDUCATION
}

$\mathrm{T}$ HIS year, half-way between the optimism of the Education Act of 1944 and the 'pessimism of Orwell's "1984", the Education Section (L) of the British Association has resolved to pass in review some of the major issues of responsibility in education. In his presidential address to this Section, Dr. F. Lincoln Ralphs attempts to indicate some of the broad issues involved and to set the stage for subsequent papers on the responsibility in education of the State, the Press, teachers, parents, etc.

Education and responsibility are held to be as inseparable as the obverse and reverse faces of a coin. By them Homo sapiens buys his right to a status unique among the animals. The educative potential of the totality of human environment must be recognized and our failure to accept responsibility in this context leads to a confusion of education with schooling and with erudition. It has led to a dichotomy between the standards advocated in school and accepted by Society. It may be there is a present preoccupation with truth at the expense of some neglect of beauty and goodness, a neglect that is excused as a revolt against hypocrisy.

Against this background the religious clauses of the 1944 Act reflect not only an attempt to reconcile the education provisions of the State and the Church but also the manifestation of war-time faith and fears in marked contrast to the present climate of thinking. There is at the present time an emphasis, even an over-emphasis, on scientific method and measurement as the only acceptable form of enquiry. Dr. Lincoln Ralphs considers that this produces a quantitative rather than a qualitative concept and is reflected in a change of emphasis from excellence and perfection to the average and the normal.

The present rapidly changing pattern of education contrasts markedly with the broad philosophy of education which had developed in the nineteenth century. "To the needs of this tranquil, stable but steadily evolving society the education and responsibility of the three R's ministered with servile conformity. Parents were as much concerned to enquire about their children's conduct as their competence. Integrity was rated as high as intellect. Manners still made man. Then, in 1914, the smouldering embers of the Balkans caught fire at Sarajevo and the world was at war. Solid structures of the past softened and melted in the new, accelerated way of life. The stage was being set for a new standard of values." The privileges of a minority in the nineteenth century became demanded as the rights of all in the twentieth, but this standardization, rationalization and certification are not necessarily the best guarantees for educational advance. "Large classes and increasing emphasis on factual knowledge which examinations tend to encourage are not calculated to inspire pupils to accept responsibility either for themselves or for others."

The responsibility of parents is basic. Their training to meet the responsibility is minimal. If the education problem begins in the home its ultimate extension is world-wide and its responsibility cannot be circumscribed in any parochial fashion. "A brain drain may be necessary if we are to deal with the effluent of ignorance that a divided world has left to poison society with prejudice and violence." In a final analysis of responsibility and education it is impossible to escape the conclusion that the central theme depends on the concept of the nature of man. "Our origins may be seen from the stern of the Beagle. Our destiny is not decided in its wake but in our own consequent involvement in the conflict of good and evil and our growing recognition of what is true and what is not true. . . . If we offer human nature as an excuse for what we no longer hope to perfect we return to the dust."

\section{THE AGE OF ADVICE}

$$
\mathrm{P}^{\mathrm{R}}
$$
ROBABLY the earliest record of science being called to the aid of agriculture is contained in the writings of John Milton the poet to Samuel Hartlib in 1651. The recommendations of other writers in the seventeenth and eighteenth centuries and the activities of the Brecknockshire and other agricultural societies from 1755 onwards undoubtedly led informed public opinion to support the private endowment of the first chair of agriculture in the University of Edinburgh in 1790.

Subsequent development, as Mr. Eric Rea points out in his presidential address to Section M. (Agriculture), was slow and spasmodic with a pronounced active period in the decade around 1840 which saw the inauguration of the Royal Agricultural Society of England, Rothamsted, the agricultural colleges at Cirencester and Glasnevin, and further chairs of agriculture at Oxford, Aberdeen and Belfast. The last thirty years of the nineteenth century saw the foundation of a number of small colleges and teaching institutes-many of them now defunctand a trio of significant events in 1889; namely, the County Councils Act; the Technical Instruction Act and the founding of the Board of A.griculture. By this means, 